\title{
TOLERANSI DAN PLURALISME WARTAWAN PARLEMEN
}

\author{
Victor Andreas Simanjuntak \\ Fakultas Ilmu Komunikasi Universitas Jayabaya \\ Victorsim80@gmail.com
}

\begin{abstract}
This research about survey of parliamentary journalist/reporter opinion to knowing about their attitude of tolerance and pluralism. Journalists as agents of delivery of information is very important in influencing the community. This research is quantitative and uses the variable $X$ (tolerance) and $Y$ (pluralism) and the influence of these two variables. The results showed the majority of journalists in the parliament owned attitude of tolerant and respect for pluralism.
\end{abstract}

\section{Keyword : Toleransi, pluralisme, wartawan, parlemen}

\section{Pendahuluan}

Indonesia merupakan negara yang majemuk, dalam artian rakyat Indonesia terdiri dari berbagai latar budaya, bahasa, agama, ras, suku dan antar-golongan. Rakyat Indonesia juga tersebar di banyak pulau, baik pulau kecil maupun besar atau pluralitas masyarakat Indonesia, menurut Retno Andriati (Ilham Nur Afian 2007: 2), dapat dilihat secara horisontal maupun vertikal.

Secara horisontal, masyarakat Indonesia dapat dikelompokkan menurut agama, ras, etnis, budaya, dan lokalitas. Secara vertikal, masyarakat Indonesia dapat dibedakan menjadi golongan atas, golongan menengah, dan golongan bawah.

Berdasarkan sensus penduduk tahun 2010 jumlah penduduk Indonesia sebesar 237.641.326 jiwa, dengan jumlah laki-laki 119.630.913 jiwa, sedangkan perempuan sebesar 118.010.413 jiwa. Sekitar 85,1\% penduduk Indonesia memeluk agama Islam, 9,2\% pemeluk agama Protestan, 3,5\% pemeluk agama Katolik, 1,8\% pemeluk agama Hindu, dan 0,4\% pemeluk agama Buddha.

Kemajemukan bangsa Indonesia ini juga menemukan sebuah persoalan dalam sikap toleransi dan penghargaan untuk berbeda atau pluralisme. Kemajemukan bangsa Indonesia ini dihadapkan pada sikap sekelompok warga yang tidak mau toleran dan menghargai perbedaan.

Munculnya konflik berbau suku, agama, ras dan antar-golongan menunjukkan adanya persoalan dalam sikap toleransi dan menghargai perbedaan atau kemajemukan atau pluralisme. Konflik ini bahkan menjurus pada konflik horisontal yang mengandung unsur kekerasan seperti konflik antar-agama (Kristen-Islam) di Ambon, Maluku atau antar penganut aliran (satu) agama seperti di Madura (Syiah dengan Suni).

Sikap tidak toleran dan tidak mau menghargai adanya perbedaan juga ditunjukkan oleh semakin menjamurnya organisasi sipil seperti Front Pembela Islam (FPI) yang mengatasnamakan agama dengan memaksakan kehendak khususnya kepada warga masyarakat yang berbeda agama. Di samping itu, sikap intoleran juga ditunjukkan warga masyarakat dalam 
kelompok kecil (lokal) yang menolak berdirinya rumah ibadah yang berbeda agama atau menentang adanya acara penyelenggaraan ibadah dari mereka yang agamanya tidak sama.

Sikap intoleran dan tidak menghargai adanya kemajemukan (pluralisme) ini semakin hari kian subur dan tidak lagi mengenal perbedaan usia dan tingkat pendidikan. Sejumlah penelitian justru menunjukkan mereka yang tinggal di kota-kota besar justru menunjukkan sikap intoleran terhadap tetangga yang berbeda agama. Beberapa penelitian juga menunjukkan warga negara yang memiliki tingkat pendidikan yang lebih baik seperti siswa Sekolah Menengah Atas (SMA) dan bahkan perguruan tinggi (PT), malah tidak menghargai adanya kemajemukan yang melekat dalam masyarakat Indonesia.

Para pendiri negara (founding fathers) menyadari bahwa adanya kemajemukan rakyat Indonesia akan memunculkan persoalan dalam integrasi sebagai bangsa dan rakyat Indonesia. Oleh karena itu, pendiri negara ini sudah memikirkan perlunya ideologi untuk bersatu yakni Pancasila serta jargon Bhineka Tunggal Ika.

Namun, kesadaran untuk bersatu sebagai bangsa dan rakyat Indonesia dengan mengedepankan sikap-sikap toleran dan menghargai kemajemukan sebagai keunikan bangsa Indonesia, masih saja menjadi persoalan.

Dalam batas ini, maka wartawan sebagai orang yang memiliki tingkat pendidikan dan pemahaman yang baik terkait masalah kemajemukan bangsa Indonesia diharapkan menjadi agen perekat dan pemersatu bangsa. Wartawan yang memiliki kekuatan sebagai agen media massa untuk mencerahkan rakyat, perannya diperlukan untuk menyebarluaskan semangat toleransi dan pluralisme.

Namun, dalam kenyataannya media massa di Indonesia kerap ikut terlibat dalam tarik menarik kepentingan terkait isu-isu konflik berbau agama. Sejumlah penelitian menunjukkan adanya keberpihakan media massa dalam menulis berita-berita yang terkait isu atau konflik yang mengandung unsur muatan SARA.

Keberpihakan media massa ini bisa saja karena faktor ideologi atau kepemilikan media. Tapi, keberpihakan media massa ini dalam sebuah isu berbau kepentingan agama, juga dipengaruhi oleh sikap dan pemahaman tentang toleransi dan penghargaan serta penghormatan terhadap kemajemukan bangsa.

Karena itulah, penelitian ini ingin mengetahui bagaimana kecenderungan sikap dan pendapat wartawan media massa cetak, elektronik dan media massa online terkait masalah toleransi dan pluralisme yang sering menjadi batu penghalang dalam proses integrasi sebagai satu bangsa dalam negara yang majemuk seperti Indonesia.

Wartawan parlemen yang menjadi sasaran dalam penelitian ini karena wartawan parlemen yang bertugas di DPR, DPD dan MPR memiliki kedekatan dengan anggota parlemen (dari latar belakang partai politik berbeda termasuk agama) dan sering mendapat penugasan untuk mencari komentar atau pendapat anggota parlemen terkait isu-isu dan konflik yang mengandung unsur intoleransi dan pluralisme. 


\section{Toleransi dan Pluralisme}

Toleransi adalah sifat atau sikap toleran yaitu bersifat atau bersikap menghargai atau bersikap, membiarkan, memperbolehkan pendirian (pendapat, pandangan, kepercayaan, kebiasaan, kelakuan, dan sebagainya) yang berbeda atau bertentangan dengan pendirian sendiri.

Sedangkan secara istilah toleransi berasal dari bahasa Latin yaitu tolerare yang berarti kelonggaran, kelembutan hati, keringanan, dan kesabaran. Secara umum, istilah ini mengacu pada sikap terbuka, lapang dada, sukarela, dan kelembutan.

Secara luas toleransi berarti suatu sikap atau perilaku manusia yang tidak menyimpang dari aturan, dimana seseorang menghargai atau menghormati setiap tindakan yang orang lain lakukan dan toleransi juga dimaknai sebagai sifat atau sikap toleran saling menghargai perbedaan suku, budaya dan agama.

Toleransi merupakan salah satu bentuk akomodasi tanpa persetujuan yang

formil. Kadang-kadang toleransi timbul secara tidak sadar dan tanpa di rencanakan, hal ini disebabkan karena adanya watak orang perorangan atau kelompok-kelompok manusia, untuk sedapat mungkin menghindarkan diri dari msuatu perselisihan.

Toleransi disini dapat diartikan juga sebagai kebebasan beragama yaitu kemerdekaan, keadaan bebas dimana manusia yang tertindas harus berjuang untuk memperoleh kebebasan hakiki (sebagai manusia) dalam hal meyakini dan mempercayai suatu dogma tertentu. Jadi dapat dipahami bahwa kebebasan beragama adalah kebebasan yang dimiliki setiap individu dalam menentukan arah keyakinan dan kepercayaan beragama. Keyakinan ini menjadi alasan kuat dan substantif untuk memilih memeluk komunitas keagamaan tertentu.

Dalam pengkajian mengenai konsep toleransi secara teoritik menurut filsuf

Amerika, Emerson Ia menawarkan gagasan tentang "keyakinan subjektif (self- reliance)".

Menurut Emerson dan Kierkegard keyakinan agama adalah sebuah paradigma dan komitmen eksistensial karena keyakinan agama pada dasarnya hanyalah konsepsi seorang yang bersifat esensial (Soerjono : 1992).

Dengan pemahaman seperti itulah orang-orang meyakini bahwa keyakinan dari masing-masing individu merupakan hak yang paling hakiki untuk memeluk keyakinan sehingga pemahaman seperti ini dapat menciptakan sikap toleransi untuk menghormati perjuangan orang lain dalam mencari keyakinan agamanya.

Perpaduan konsep toleransi juga diutarakan oleh Josiah Royce. Ia menekankan pada pentingnya loyalitas komitmen personal dan keyakinan tulus. Artinya manusia sebagai makhluk sosial sepatutnya menghargai loyalitas-loyalitas orang lain selama loyalitas-loyalitas tersebut tidak bertujuan pada tindakan- tindakan destruktif (merusak).

Dalam pandangan Royce, toleransi juga berperan dalam melahirkan sikap penghargaan terhadap perbedaan yang ada, dengan tetap menjunjung loyalitas orang lain, serta mampu mengendalikan loyalitas pribadi agar tidak menimbulkan individualisme yang menegasikan loyalitas kelompok lain. 
Hal sama diutarakan oleh Wazler.

Wazler (1997) memandang toleransi sebagai keniscayaan dalam ruang individu dan ruang publik karena salah satu tujuan toleransi adalah membangun hidup damai (peaceful coexistence) di antara pelbagi kelompok masyarakat dari berbagai perbedaan latar belakang sejarah, kebudayaan dan identitas.

Toleransi menurut Wezler, harus mampu membentuk kemungkinan-kemungkinan sikap, antara lain sikap menerima adanya perbedaan, mengubah penyeragaman menjadi keragaman, mengakui hak orang lain, menghargai eksistensi orang lain dan mendukung secara antusias terhadap perbedaan budaya dan keragaman ciptaan Tuhan. Yang terakhir kemudian populer dengan istilah multikulturalisme.

Pluralisme berasal dari bahasa Inggris yang berakar dari kata "plural" yang berarti banyak atau majemuk. Atau meminjam definisi Martin $\mathrm{H}$. Manser dalam Oxford Learner's Pocket Dictionary: "Plural (form of a word) used of referring to more than one". (Marsen Martin : 2009). Sedangkan dalam Kamus Ilmiah Populer, pluralisme berarti: "Teori yang mengatakan bahwa realitas terdiri dari banyak substansi”.

Menurut Alwi Shihab (2002), pengertian pluralisme dapat disimpulkan menjadi tiga yaitu: pertama, pluralisme tidak semata menunjuk pada kenyataan tentang adanya kemajemukan. Namun, yang dimaksud pluralisme adalah keterlibatan aktif terhadap kenyataan kemajemukan tersebut.

Kedua, pluralisme harus dibedakan dengan kosmopolitanisme. Dalam hal ini Kosmopolitanisme menunjuk suatu realitas di mana aneka ragam ras dan bangsa hidup berdampingan di suatu lokasi. Maksudnya walaupun suatu ras dan bangsa tersebut hidup berdampingan tetapi tidak ada interksi sosial. Ketiga, konsep pluralisme tidak dapat disamakan dengan relativisme. Paham relativisme menganggap "semua agama adalah sama".

Keempat, pluralisme agama bukanlah sinkretisme, yakni menciptakan suatu agama baru dengan memadukan unsur tertentu atau sebagian komponen ajaran dari beberapa agama untuk dijadikan bagian integral dari agama tersebut.

Sementara itu,Syamsul Ma'arif (2005) mendefinisikan pluralisme adalah suatu sikap saling mengerti, memahami, dan menghormati adanya perbedaan-perbedaan demi tercapainya kerukunan antarumat beragama. Dan dalam berinteraksi dengan aneka ragam agama tersebut, umat beragama diharapkan masih memiliki komitmen yang kokoh terhadap agama masingmasing.

Menurut Nurcholis Majid pluralisme tidak dapat dipahami hanya dengan mengatakan bahwa masyarakat kita majemuk, beraneka ragam, terdiri dari berbagai suku dan agama yang justru hanya mengambarkan kesan fragmentasi bukan pluralisme. Pluralisme juga tidak boleh difahami sekdar kebaikan negatif, hanya ditilik dari kegunaannya untuk menyingkirkan fanatisme. Pluralisme harus difahami sebagai pertalian sejati kebhinekaan dalam ikatan-ikatan keadaban.

Di Indonesia Pluralisme dilambangkan dengan moto Bhineka Tunggal Ika. Negeri ini terdiri dari berbagai pulau, suku bangsa, tradisi, agama dan lain-lain. Karena, itu Indonesia memerlukan pengembangan konsep pluralisme untuk mempertahankan persatuannya. 
Penyajian informasi berupa berita kepada khalayak tidak lepas dari peran utama seorang wartawan. Wartawan harus memiliki sifat dasar yang dapat memotivasinya dalam bekerja. Sikap dasar yang pertama bagi wartawan ialah rasa ingin tahu yang tinggi terhadap informasi. Sikap dasar berikutnya yang harus dimiliki olehwartawan ialah menggali informasi seluas-luasnya mengenai kasus yang akan diberitakan.

Di dalam pandangan konstruksionis, wartawan tidak bisa menyembunyikan pilihan moral dan keberpihakkannya, karena ia merupakan bagian yang intrinsik dalam pembentukan berita. Fakta tidak diambil begitu saja, tidak ada realitas yang bersifat eksternal dan objektif yang berada di luar diri wartawan. (Zaenuddin : 2007)

Realitas itu dibentuk dan diproduksi tergantung pada bagaimana proses konstruksi berlangsung. Realitas yang terbentuk dalam pemberitaan bukanlah apa yang terjadi dalam dunia nyata, melainkan relasi antara wartawan dengan sumber dan lingkungan sosial yang membentuknya.

Praktik membuat liputan berita memihak satu pandangan, menempatkan pandangan satu lebih penting dibandingkan pandangan kelompok lain yang oleh pendekatan positivistik dianggap tidak benar, dalam pendekatan konstruksionis dipandangsebagai praktik jurnalistik. (Sudirman : 2007)

Ada dua kriteria atau persyaratan yang dapat dikatakan merupakan tuntutan atau panduan bagi wartawan dalam melakukan proses rekonstruksi realitas. Pertama, kriteria atau persyaratan teknis misalnya, sebuah laporan jurnalisme sebaiknya memiliki kelengkapan $5 \mathrm{~W}+1 \mathrm{H}$ (what, who, where, when, why, dan how). Kemudian berkaitan dengan jenis berita apakah hard news, soft news, spot news, developing news atau continuing news.

Konstruksi realitas yang disusun oleh wartawan untuk menjadi calon berita ini diharapkan memiliki nilai berita (news value) yang penting dan menarik. Kedua, persyaratan yang berkaitan dengan kualitas atau bobot produk berita. Kualitas atau bobot produk berita ini berarti produk jurnalisme surat kabar atau majalah hendaknya bersifat objektif.

Wartawan dalam melakukan proses konstruksi realitas masih dipengaruhi oleh dua faktor lagi, yaitu faktor konteks eksternal dan faktor konteks internal yang terdiri dari internal institusi dan internal individu.

Faktor konteks eksternal misalnya, sistem politik yang berlaku pada suatu negara dapat pula mempengaruhi institusi surat kabar, khususnya wartawan dalam mengkonstruksi realitas sehingga pada akhirnya dapat pula mempengaruhi penampilan dari isi atau perwajahan sebuah surat kabar. Faktor konteks internal, internalinstitusi berarti bahwa setiap institusi surat kabar memiliki motif atau kepentinganyang berbeda satu dengan yang lain sedangkan internal individu berarti bahwa individu wartawan sendiri ketika bekerja merekonstruksi realitas bukan merupakan individu yang pasif.

Wartawan mengkonstruksikan masyarakat dan berbagai kenyataan sosial. Aktifitas tersebut menghadapkan wartawan pada dua kenyataan yakni kenyataan subjektif dan kenyataan objektif sebagai bagian dari masyarakat yang pada akhirnya ia menginternalisasikan kenyataan tersebut sebagai bagian dari kesadarannya.

Realitas bukanlah sesuatu yang berada di luar yang bersifat obyektif, benar dan seakan-akan ada sebelum diliput oleh wartawan. Sebaliknya, realitas itu dibentuk dan diproduksi tergantung pada bagaimana proses konstruksi berlangsung. Realitas itu sebaliknya bersifat subjektif 
yang terbentuk lewat pemahaman dan pemaknaan subjektif wartawan.

Fungsi media massa menyebarkan informasi kepada khalayak. Khalayak selalu haus akan informasi tentang segala sesuatu yang terjadi di sekitarnya. Semakin berkembangnya teknologi saat ini pun, telah memberikan kontribusi besar dalam penyebaran informasi. Komunikasi media massa semakin canggih dan kompleks serta memiliki kekuatan yang lebih dari masa ke masa.

Di dalam pandangan kaum konstruksionis, media dilihat bukan sebagai saluran yang bebas seperti yang dipandang oleh kaum positivis. Media ialah subjek yang mengkonstruksikan realitas, lengkap dengan pandangan, bias dan pemihakkannya. Media dipandang sebagai agen konstruksi sosial yang mendefinisikan realitas. Dalam hal ini digambarkan, bagaimana media memahami dan memaknai sebuah realitas dan dengan cara apa realitas itu dibingkai oleh media.

Gitlin menyatakan bahwa bingkai media adalah pola yang selalu ada dalam bentuk kognisi, interpretasi dan presentasi dari seleksi, penekanan atau pengucilan.

Bingkai media diperlihatkan melalui konsepsi dan skema interpretasi wartawan dalam menyusun, mengisahkan, menulis dan menekankan fakta dari suatu peristiwa tertentu. Setiap berita memiliki bingkai yang menjadi pusat ide. Apa yang tersaji dalam berita yang kita baca setiap hari adalah produk dari pembentukan realitas oleh media.

Dari kajian teori yang telah dipaparkan di atas hipotesa yang dapat penulis ajukan sebagai berikut:

Ha : Pemahaman mengenai pluralisme agama berpengaruh positif terhadap sikap toleransi yang dimiliki wartawan yang bertugas di parlemen (DPR, DPD dan MPR)

Ho :Pemahaman mengenai pluralisme agama tidak berpengaruh terhadap sikap toleransi yang dimilikiwartawan yang bertugas di parlemen (DPR, DPD dan MPR)

\section{Metode Penelitian}

Penelitian ini bersifat kuantitaitf dengan melakukan pengukuran secara akurat menggunakan perhitungan statistic mengenai pemahaman wartawan parlemen atas pluralism agama serta pengaruhnya terhadap sikap toleransi beragama yang dimiliki.

Pendekatan kuantitatif digunakan dalam penelitian ini karena peneliti hendak mengujikebenaran teori.Oleh karena itu, peneliti akan menggunakan prosedur yang sesuai dengan penelitian kuantitaitf.

Metode penelitian kuantitatif dapat diartikan sebagai metode penelitian yang berlandaskan pada filsafat positivism, digunakan untuk meneliti pada populasi atau sampel tertentu, teknik pengambilan sampel pada umumnya dilakukan secara random, pengumpulan data menggunakan instrument penelitian, analisa data bersifat kuantitatif/statistik dengan tujuan untuk menguji hipotesis yang telah diterapkan.

Metode pengumpulan data merupakan salah satu aspek yang berperan dalam kelancaran dan keberhasilan dalam suatu penelitian. Dalam penelitian ini metode pengumpulan data yang digunakan adalah sebagai berikut:

1. Angket atau Kuesioner 
Angket atau kuesioner adalah teknik pengumpulan data melalui formulir-formulir yang berisi pertanyaan-pertanyaan yang diajukan secara tertulis pada seseorang atau sekumpulan orang untuk mendapatkan jawaban atau tanggapan dan informasi yang diperlukan oleh peneliti (Mardalis: 2008: 66) Penelitian ini menggunakan angket atau kuesioer, daftar pertanyaannya dibuat secara berstruktur denan bentuk pertanyaan pilihan berganda (multiple choice questions) dan pertanyaan terbuka (open question). Metode ini digunakan untuk memperoleh data tentang persepsi desain interior dari responden.

2. Metode Dokumentasi

Metode dokumentasi yaitu pengumpulan data dimana peneliti menyelidiki benda-benda tertulis seperti buku-buku, majalah, dokumen, peraturanperaturan, dan sebagainya (Arikunto, 2002: 158). Metode ini digunakan untuk memperoleh data tentang jumlah wartawan yang bertugas di gedung parlemen.

Target populasi yang menjadi sasaran penelitian ini adalah wartawan yang bertugas di parlemen (DPR, DPD dan MPR) yang berjumlah 87 orang. Wartawan menjadi objek penelitian karena mereka telah memperoleh pengetahuan tentang masalah pluralisme semasa mereka bertugas di parlemen.

Pengambilan sampel dalam penelitian ini menggunakan metode probability random sampling yang memberikan kesempatan yang sama kepada semua anggota populasi. Namun, karena jumlah populasi yang kurang dari 100 maka diputuskan untuk melibatkan keseluruhan populasi yang berjumlah 87 wartawan untuk menjadi responden dalam penelitian ini.

Dari 87 kuesioner yang disebar hanya 71 kuesioner yang layak untuk diolah dan sisanya 16 kuesioner tidak dapat diolah karena responden tidak mengisi kuesioner secara tuntas.

Penelitian dilaksanakan di Gedung Parlemen, Senayan, Jakarta. Waktu penelitian dilaksanakan pada 12 Agustus 2016. Dalam kurun waktu ini, data yang dikumpulkan dan dianalisa untuk mengetahui bagaimana persepsi wartawan parlemen terhadap pluralisme agama serta bagaimana sikap toleransi mereka dalam hal beragama.

\section{Pemahaman terhadap pluralisme agama $(\mathbf{X})$}

Variabel pemahaman terhadap pluralisme agama dalam penelitian ini digunakan untuk mengukur bagaimana pemahaman wartawan parlemen mengenai pluralism agama dengan mendasarkan kepada dua konstruksi pemikiran wacana pluralism agama di Indonesia yaitu fundamentalis dan moderat. Untuk itu, instrumen untuk mengukur pemahaman wartawan parlemen mengenai pluralism agama akan disusun secarapositif (favorably) dan secara negatif (unfavorably). 
Tabel 2.1 : Instrumen untuk variable pemahaman mengenai pluralisme agama

\begin{tabular}{|c|c|c|}
\hline No & $\begin{array}{l}\text { PERTANYAAN } \\
\text { UNFAVORABLY }\end{array}$ & PERTANYAAN FOVARABLY \\
\hline 1 & $\begin{array}{l}\text { Pluralisme agama bertentangan } \\
\text { dengan Islam karena } \\
\text { mengajarkan bahwa Tuhan dan } \\
\text { kebenaran tidak } \\
\text { hanyadimonopoli oleh satu } \\
\text { agama saja }\end{array}$ & $\begin{array}{l}\text { Pluralisme agama mengajarkan kepada kita } \\
\text { untuk menghomati dan menghargai } \\
\text { keyakinandan kepercayaan kepada Tuhan dan } \\
\text { pemeluk umat yang berbeda }\end{array}$ \\
\hline 2 & $\begin{array}{l}\text { Pluralisme agama bertentangan } \\
\text { dengan Islam karena } \\
\text { mengajarkan bahwa surge tidak } \\
\text { hanya dimiliki umat tertentu } \\
\text { saja, artinya semua pemeluk } \\
\text { agama berhak masuk surga }\end{array}$ & $\begin{array}{l}\text { Pluralisme agama mengajarkan bahwa } \\
\text { keberagaman agama adalah kekayaan bangsa } \\
\text { yang harus dijaga }\end{array}$ \\
\hline 3 & $\begin{array}{l}\text { Pluralisme agama itu } \\
\text { bertentangan dengan Islam } \\
\text { karena menyamakan semua } \\
\text { agama }\end{array}$ & $\begin{array}{l}\text { Pluralisme agama mengajarkan kepada kita } \\
\text { bahwa toleransi bukan hanya sekadar } \\
\text { menghormati kepercayaan dan keyakinan } \\
\text { umat yang berbeda, namun turut serta aktif } \\
\text { berpartisipasi dalam kegiatan-kegiatan sosial } \\
\text { yang positif }\end{array}$ \\
\hline 4 & $\begin{array}{l}\text { Pluralisme bertentangan } \\
\text { dengan Islam karena } \\
\text { meniadakan perbedaan antara } \\
\text { Islam dan kekafiran, kebenaran } \\
\text { dan kebatilan, perbuatan } \\
\text { baikdan kemungkaran serta } \\
\text { menghancurkan perbedaan } \\
\text { antaramuslimdan kafir }\end{array}$ & $\begin{array}{l}\text { Pluralisme agama mengajarkankepada kita } \\
\text { untuk tidakmemaksakan pandangan dan } \\
\text { keyakinan kepada pemeluk agama yang } \\
\text { berbeda keyakinan }\end{array}$ \\
\hline 5 & $\begin{array}{l}\text { Pluralisme agama bertentangan } \\
\text { dengan Islam Karena bentuk } \\
\text { kemurtadan dari agama Islam } \\
\text { dengan sangat nyata karena } \\
\text { pluralism agama dapat } \\
\text { menggoyahkan keyakinan } \\
\text { seorang muslim }\end{array}$ & $\begin{array}{l}\text { Pluralisme agama mengajarkan kepada kita } \\
\text { untuk tidak saling mengkafirkan antar-umat } \\
\text { yang berbeda }\end{array}$ \\
\hline
\end{tabular}

Instrumen di atas akan diukur rmenggunakan skala sikap. Untuk instrumen yang disusun secara unfavorably pengukuran dilakukan dengan ketentuan, skor 1 jika "sangat setuju", skor 2 jika "setuju", skor 3 jika "setuju" dan skor 4 jika "sangat setuju".

\section{Sikap Toleransi dalam Beragama (Y)}

Variabel sikap toleransi digunakan untuk mengukur tingkat toleransi yang dimiliki wartawan parlemen berdasarkan respons mereka terhadap bentuk-bentuk pelanggaran berbasis agama yang terjadi di Indonesia, 
berdasarkan laporan dari beberapa lembaga terkait.

Pengukuran dilakukandengan ketentuan, skor 1 jika "sangat setuju", skor 2 jika "setuju", skor 3 jika "tidak setuju" dan skor 4 jika "sangat tidak setuju".

Berikut dijelaskan dalam tabel 2.2

Tabel 2.2 : Instrumen untuk variable toleransi

\begin{tabular}{|c|c|c|c|c|c|}
\hline NO & PERTANYAAN & \multicolumn{4}{|c|}{$\begin{array}{l}\text { KRITERIA } \\
\text { PILIHAN }\end{array}$} \\
\hline & & SS & $\mathbf{S}$ & TS & STS \\
\hline 1 & $\begin{array}{l}\text { Tindakan warga yang menolak pelaksanaan } \\
\text { ibadah pemeluk agama lain }\end{array}$ & & & & \\
\hline 2 & $\begin{array}{l}\text { Tindakan warga yang menolak } \\
\text { pembangunan rumah ibadah agama lain }\end{array}$ & & & & \\
\hline 3 & $\begin{array}{l}\text { Tindakan warga yang merusak tempat } \\
\text { ibadah agama lain }\end{array}$ & & & & \\
\hline 4 & $\begin{array}{l}\text { Tindakan warga yang menolak guru karena } \\
\text { agamanya berbeda }\end{array}$ & & & & \\
\hline 5 & $\begin{array}{l}\text { Tindakan warga yang menentang kegiatan } \\
\text { keagamaan yang dilakukan oleh aliran } \\
\text { keagamaan yang dianggap menyimpang }\end{array}$ & & & & \\
\hline 6 & $\begin{array}{l}\text { Tindakan warga yang merusak } \\
\text { rumah/fasilitas milik anggota aliran } \\
\text { keagamaan yang dianggap menyimpang }\end{array}$ & & & & \\
\hline 7 & $\begin{array}{l}\text { Tindakan warga yang menolak kehadiran } \\
\text { kelompok keagamaan tertentu karena } \\
\text { dianggap menyimpang }\end{array}$ & & & & \\
\hline 8 & $\begin{array}{l}\text { Tindakan warga yang merusak/menyegel/ } \\
\text { tempat-tempat iburan (café, bar dan tempat } \\
\text { perjudian) }\end{array}$ & & & & \\
\hline 9 & $\begin{array}{l}\text { Larangan untuk mengucapkan selamat hari } \\
\text { raya untuk umat agama yang berbeda }\end{array}$ & & & & \\
\hline 10 & $\begin{array}{l}\text { Membangun masjid di samping rumah } \\
\text { ibadah umat agama yang berbeda }\end{array}$ & & & & \\
\hline
\end{tabular}

Data yang telah terkumpul selanjutnya diolah. Semua data yang terkumpul kemudian disajikan dalam susunan yang baik dan rapi. Yang termasuk dalam kegiatan pengolahan data adalah menghitung frekuensi mengenai pengaruh desain interior terhadap minat berkunjung masyarakat berdasarkan data hasil kuesioner kemudian diolah untuk mendapatkan nilai persentase.

Tahap-tahap pengolahan data tersebut adalah:

1. Penyuntingan 
Semua daftar pertanyaan wawancara, data kuesioner yang berhasil dikumpulkan selanjutnya diperiksa terlebih dahulu dan dikelompokkan.

2. Penyusunan dan Perhitungan Data

Penyusunan dan perhitungan data dilakukan secara manual dengan menggunakan alat bantu berupa komputer.

3. Tabulasi

Data yang telah disusun dan dihitung selanjutnya disajikan dalam bentuk tabel. Pembuatan tabel tersebut dilakukan dengan cara tabulasi langsung karena data langsung dipindahkan dari data ke kerangka tabel yang telah disiapkan tanpa proses perantara lainnya. (Singarimbun, 1994: 248).

\section{Hasil dan Pembahasan}

Berikut hasil temuan peneliti di lapangan terkait pemahaman wartawan di parlemen tentang pluralism agama dan dampaknya terhadap sikap toleransi agama yang mereka miliki. Berdasarkan karakteristik responden dalam penelitian ini;

\section{Tabel 3.1 Karakteristik Responden}

$\begin{array}{lll}\text { Kategori } & \text { Frekuensi } & \text { Persentase }\end{array}$

Jenis Kelamin

Laki-laki

63

88,7

Perempuan

Total

8

11,3

71

100.0

Jenis Media Massa

Suratkabar

55

77,5

Televisi dan Radio

11

5

15,5

Media Internet

71

7

100.0

Telah Mengikuti Mata kuliah Pancasila atau Kewarganegaraan

Sudah

66

93.0

Belum

5

7.0

Total

71

100.0

Dari tabel 3.1 terlihat bahwa karakteristik responden berdasarkan jenis kelamin adalah total 71 responden sebanyak 63 (88,7 persen) berjenis kelamin laki-laki dan sisanya 8 (11,3 persen) berjenis kelamin perempuan. Sehingga dapat disimpulkan mayoritas yang menjadi responden adalah berjenis kelamin laki-laki.

Jika dilihat dari jenis media massanya, yang terbesar adalah responden wartawan dari media massa cetak yaitu suratkabar atau majalah yakni sebesar 55 orang (75,5 persen), dan sisanya adalah wartawan dari media massa elektronik yaitu televisi dan radio sebanyak 11 orang (15,5 persen) dan terakhir dari wartawan media internet sebanyak 5 orang (7 persen). 
Sedangkan dilihat dari apakah mereka sudah mengikuti mata kuliah Pancasila atau Kewarganegaraan, mayoritas responden atau 66 orang (93 persen) sudah mengikutinya di bangku kuliah sementara sisanya 5 responden ( 7 persen) mengaku belum pernah mengikuti.

\section{A. Pemahaman Wartawan Parlemen Terkait Pluralisme Agama}

Diagram 3.1 di bawah ini merupakan rekapitulasi secara keseluruhan dari respons wartawan parlemen terkait pernyataan bahwa pluralism agama bertentangan dengan Islam.

Dari total responden mayoritas memberikan respons ketidaksetujuannya bahwa pluralisme agama bertentangan dengan Islam. Angka ketidaksetujuan tertinggi berada pada pernyataan bahwa pluralismesama dengan menyamakan agama yaitu sebesar 64,79 persen.

Selanjutnya diikuti oleh pernyataan bawah pluralism agama menghilangkan batas antara Islam dan kafir serta dapat menggoyahkan iman sebesar 59,15 persen. Selain itu, angka ketidaksetujuan yang tinggi juga tampak pada pernyataan bahwa pluralisme agama bertentangan karena menganggap Tuhan, surga dan kebenaran tidak dimnopoli oleh satu agama saja yaitu sebesar 50,70 persen.

Di pihak lain respons ketidaksetujuan terhadap pernyataan bahwa pluralisme bertentangan dengan Islam juga muncul dari sebagian wartawan parlemen terlihat sebesar 35,21 persen setuju bahwa pluralisme bertentangan karena mengajarkan jika surga tidak dimonopoli oleh satu agama saja.

Kemudian sebesar 26,76 persen responden menyatakan setuju jika pluralisme bertentangan dengan Islam karena mengajarkan bahwa Tuhan dan kebenaran tidak dimonopoli oleh satu agama saja. Sementara itu, sebanyak 22,54 persen responden mengaku setuju jika pluralisme agama bertentangan dengan Islam karena menyamakan agama serta meniadakan perbedaan antara Islam dan kafir serta dapat menggoyahkan keyakinan seorang muslim.

Secara keseluruhan jika peneliti amati hasil ini merupakan indikasi bahwa mayoritas pemahaman wartawan parlemen terkait pluralism agama ke arah yang positif artinya tidak ada penolakan terhadap wacana pluralisme. Namun demikian, dari hasil rekapitulasi perhitungan kuesioner seputar pluralisme agama masih ada sebagian kecil responden yang memberikan kesetujuannya terhadap pernyataan bahwa pluralisme agama bertentangan dengan Islam.

Kemudian dari diagram 3.2 nampak bahwa jawaban responden terkait pernyataan seputar pluralisme agama yang disusun secara vafourable, mayoritas menunjukkan kesetujuannya bahwa pluralisme mengajarkan hal-hal yang positif. Terlihat bahwa mayoritas 57,7 persen mereka setuju jika pluralisme agama mengajarkan bahwa keberagaman merupakan kekayaan bangsa yang harus dijaga dan mengajarkan untuk tidak saling mengkafirkan antar-pemeluk agama yang berbeda.

Kemudian sebesar 53,52 persen, wartawan parlemen setuju jika pluralisme agama mengajarkan untuk menghormati dan menghargai keyakinan antarpemeluk agama. Di sisi lain, sebesar 53,52 persen wartawan parlemen setuju bahwa pluralisme agama mengajarkan untuk tidak memaksakan pandangan dan keyakinan kepada pemeluk agama yang berbeda.

Hasil penelitian menunjukkan sebesar 46,48 persen sangat setuju bahwa pluralisme agama mengajakan bahwa toleransi bukan hanya sekadar menghormati, namun turut serta aktif berpartisipasi dalam kegiatan-kegiatan sosial yang positif.

Namun, ada juga sebagian kecil dari wartawan parlemen yang menyatakan 
ketidaksetujuannya jika pluralisme agama mengajarkan hal-hal yang positif. Seperti pada temuan sebelumnya ada sebagian dari wartawan parlemen yang menunjukkan respons tidak setuju jika pluralisme agama mengajarkan hal-hal yang positif dalam kehidupan beragama. Ini terlihat ada sebesar 4,23 persen tidak setuju jika pluralism agama mengajarkan untuk tidak saling mengkafirkan antarumat agama yang berbeda.

Namun, jika dilihat secara keseluruhan mengenai respons wartawan parlemen terhadap isu-isu seputar pluralism agama cenederung ke arah yang positif, artinya mereka setuju dan bahkan sangat setuju jika pluralisme agama mengajakarn nilainilai yang positif seputar kehidupan sosial keagamaan.

\section{B. Toleransi Agama Wartawan Parlemen}

Dari diagram 3.3 dapat diketahui secara keseluruhan mayoritas responden cenderung menunjukkan ketidaksetujuannya terhadap tindakan-tindakan yang melanggar kebebasan beragama di Indonesia.

Secara spesifik dari diagram di atas terlihat bahwa mayoritas sebesar 67,61 persen wartawan parlemen tidak setuju terrhadap tindakan warga yang menolak pembangunan rumah ibadah pemeluk agama lain. Namun, ada sebagian kecil yaitu sebesar 5,63 persen setuju terhadap tindakan tersebut dan bahkan sebesar 5,63 persen juga menyatakan setuju terhadap tindakan yang melanggar kebebasan kehidupan beragama di Indonesia tersebut.

Kemudian sebesar 66,20 persen dari wartawan parlemen menyatakan ketidaksetujuannya terhadap tindakan warga yang menolak guru karena agamanya berbeda dan ada 4,22 persen responden yang menyatakan setuju bahkan sangat setuju terhadap aksi penolakan guru hanya karena memiliki agama yang berbeda.

Mengenai tindakan warga yang menolak aktivitas ibadah pemeluk agama lain, terlihat respons wartawan parlemen yang menunjukkan sebesar 52,11 persen menyatakan tidak setuju dan 32,39 persen sangat tidak setuju terhadap tindakan tersebut. Sisanya, sebesar 5,63 persen menyatakan setuju dan sangat setuju terhadap tindakan warga yang menolak aktivitas ibadah pemeluk agama yang berbeda.

Sedangkan mengenai kasus pengrusakan tempat ibadah kelompok agama yang dianggap sesat (dalam kasus ini Syiah dan Ahmadiyah), sebesar 46,48 persen wartawan parlemen menyatakan tidak setuju dan 33,80 persen menyatakan sangat tidak setuju. Sisanya, sebesar 14,08 persen menyatakan setuju dan 5,63 persen menyatakan sangat setuju terkait kasus tersebut.

Kemudian mengenai tindakan warga yang merusak rumah/fasilitas milik anggota aliran keagamaan yang menyimpang, terlihat sebesar 60,58 persen menyatakan tidak setuju dan 25,35 persen sangat tidak setuju. Sementara sebesar 9,68 persen menyatakan setuju dan 4,22 persen sangat setuju.

Sedangkan untuk tindakan warga yang menolak kehadiran kelompok keagamaan tertentu karena dianggap sesat, sebesar 52,11 persen wartawan parlemen menyatakan tidak setuju dan 15,49 persen sangat tidak setuju dan sisanya sebesar 28,17 persen menyatakan setuju dan 4,22 persen menyatakan sangat setuju.

Kemudian mengenai tindakan warga yang merusak dan menyegel tempat hiburan (seperti café, bar dan tempat perjudian) sebesar 42,25 persen responden menyatakan tidak setuju dan 8,45 persen menyatakan sangat tidak setuju. Di sisi lain, sebesar 30,99 persen menyatakan setuju dan 12,68 persen menyatakan sangat setuju terhadap tindakan tersebut.

Mengenai larangan untuk mengucapkan selamat hari raya kepada umat agama 
yang lain, sebesar 49,30 persen menyatakan sangat tidak setuju, 8,45 persen menyatakan sangat tidak setuju. Sedangkan untuk yang setuju diketahui ada sebesar 30,99 persen dan 8,45 persen menyatakan sangat setuju untuk tidak mengucapkan selamat hari raya kepada umat agama yang berbeda.

Terakhir, mengenai pembangunan masjid di samping tempat ibadah umat agama yang berbeda terlihat jika mayoritas sebesar 52,11 persen menyatakan setuju dan 11,27 persen menyatakan sangat tidak setuju. Sedangkan sebesar 25,35 persen menyatakan tidak setuju dan 11,27 persen menyatakan sangat tidak setuju.

Hal yang menarik dari temuan di atas adalah bahwa ada sebagian kecil dari wartawan parlemen yang setuju terhadap tindakan-tindakan secara hukum melanggar kebebasan beragana di Indonesia. Walaupun demikian, jika dilihat secara keseluruhan kecenderungan yang muncul adalah bahwa responden tidak setuju terhadap tindakan-tindakan yang melanggar kebebasan kehidupan beragama di Indonesia.

Sehingga dapat disimpulkan bahwa mayorityas wartawan yang bertugas di parlemen (DPR, MPR dan DPD) memiliki sikap toleransi kehidupan beragama yang tinggi.

\section{Korelasi Pemahaman terhadap Pluralisme Agama dan Toleransi}

Untuk mengetahui ada tidaknya hubungan antara pemahaman plkuralisme agama dan sikap toleransi yang dimiliki wartawan yang bertugas di parlemen maka peneliti menggunakan teknik analisa korelasi product mommen (person)). Batas toleransi kesalahan yang digunakan adalah sebesar 0,05 .

\section{Tabel 3.5 Hasil Perhitungan Korelasi}

\begin{tabular}{llcc}
\hline & \multicolumn{2}{c}{ Indeks Pluralisme } & Indeks Toleransi \\
\hline Indeks Pluralisme & $\begin{array}{l}\text { Pearson Correlation } \\
\text { Sig. (2 -tailed) }\end{array}$ & 1 & .493 \\
& $\mathrm{~N}$ & 71 & .000 \\
& & & 71 \\
\hline Indeks Toleransi & Pearson Correlation & .493 & \\
& Sig. (2 -tailed) & .000 & \\
& $\mathrm{~N}$ & 71 & 71 \\
\hline
\end{tabular}

\section{Correlation is significant at the 0.05 level (2-tailed)}

Dari hasil perhitungan korelasi seperti yang terlihat pada table 3.5 di atas, dapat kita ketahui bahwa besarnya hubungan yang terjadi antara pemahaman mengenai pluralisme agama dan sikap toleransi yang dimiiki adalah sebesar 0,439 (44 persen) angka koefisien korelasi tersebut jika dibandingkan dengan table intepretasi korelasi person berarti hubungan yang terjadi antara dua variable tersebut adalah sedang.

Di sisi lain, angka signifikansi perhitungan korelasi sebesar 0.;00. Sehingga karena kesalahan (alpha) lebih kecil dari 0,05 dengan kata lain pada angka kepercayaan 95 persen terdapat hubungan yang signifikan antara pemahamana mengenai pluralisme agama dan sikap toleransi yang dimiliki wartawan parlemen.

Selain itu angka koefisien korelasi tidak menunjukkanj tanda negatif (-) maka dapat disimpulkan bahwa arah hubungan yangn terjadi adalah positif, artinya terjadi hubungan yang searah antara pemahaman mengenai sikap pluralisme 
agama dan sikap toleransi. Dengan kata lain, semakin tinggi pemahaman mengenai pluralism agama semakin tinggi pula sikap toleransi beragama yang dimiliki.

Analisa korelasi tidaklah cukup dan kuat untuk menganalisa hubungan antara pemahaman mengenai pluralisme agama dan sikap toleransi beragama. Untuk itu, analisa regresi akan peneliti gunakan untuk memperkuat analisa korelasi yang sudah peneliti paparkan di atas.

Analisa regresi bertujuan: pertama, untuk,mengetahui secara statistik seberapa besar pengaruh variabel pemahaman mengenai pluralisme agama terhadap sikap toleransi beragama. Kedua, untuk membuat prediksi (nilai estimasi) peningkatan besarnya sikap toleransi beragama jika terjadi perubahan nilai pada variabel pemahaman mengenai pluralism agama.

Berikut ini perhitungan analisa regresi dengan menggunakan alat bantu SPSS

Tabel 3.6 : Hasil Perhitungan Regresi

\begin{tabular}{llccccc}
\hline & & \multicolumn{2}{c}{$\begin{array}{l}\text { Understandardized } \\
\text { Coefficients }\end{array}$} & \multicolumn{2}{c}{$\begin{array}{l}\text { Standardized } \\
\text { Coefficients }\end{array}$} \\
\hline Model & & B & Std Error & 1 & Sig \\
\hline 1 & & (Constant) & .266 & .095 & 2.793 & .027 \\
& Indeks Pluralisme & .582 & .123 & 4.712 & .000 \\
& & & & & \\
\hline
\end{tabular}

Dari table 3.6 di atas terlihat bahwa nilai koefisien regresi consctant sebesar 0,27 (0.2666) ini berarti bahwa rata-rata sikap toleransi wartawan parlemen apabila tidak memiliki pemahaman sama sekali mengenai pluralism agama adalah sebesar 0,27 atau jika dipresentasekan menjadi 27 persen.

Kemudian angha koefisen regresi untuk variabel pemahaman mengenai pluralisme agama (..) sebesar 0,58 (0.582) berarti rata-rata sikap toleransi beragama yang dimiliki wartawan parlemen sebesar 0.58 atau jika dipresentasekan menjadi 58 persen apabila tingkat pemahaman mengenai pluralisme agama naik sebesar 1 persen (0.01).

Dari analisa tersebut nampak bahwa ada perubahan nilai besarnya sikap toleransi beragama sebeluk dan sesudah memperoleh pengaruh dari variable pemahaman mengenai pluralisme agama.

Di sisi lain, angka siginifikansi koefisien regresi pemahaman mengenai pluralism agama sebesar 0.00 yang berarti lebih kecil dari alpha (0.05.sehingga dapat disimpulkan pada angka kepercayaan 95 persen, variabel pemahaman mengenai pluralisme agama berpengaruh secara nyata terhadap sikap toleransi beragama yang dimiliki wartawan parlemen.

Dengan kata lain, hipotesa alternatif berbunyi "ada pengaruh yang positif signifikan tingkat pemahaman mengenai pluralisme terhadap sikap toleransi beragama yang dimilki wartawan parlemen" dan hipotesa nihil ditolak.

Kemudian untuk mengetahui seberapa besar pengaruh pemahaman mengenai pluralisme agama terhadap sikap toleransi agama yang dimiliki wartawan parlemen bisa dilihat pada tabel berikut; 
Tabel 3.7: Hasil Perhitungan Koefisien Determinasi

Std. Error 0

\begin{tabular}{cccccc} 
Model & R & R Square & Adjusted R & Square & f \\
\hline 1 & .493 & .243 & .233 & .11010
\end{tabular}

\section{a. Predictors : (Contant), Indeks.pluralisme}

Dari tabel 3.7 di atas terlihat bahwa angka koefisien determinasi variable pemahaman mengenai pluralism (R2) sebesar 0.243 yang berarti sikap toleransi dapat dijelaskan oleh variable pemahaman mengenai pluralisme sebesar 24 persen dan sisanya 76 persen sikap toleransi agama yang dimiliki wartawan parlemen dijelaskan oleh varabel lain yang tidak dimasukkan dalam penelitian ini.

Dengan kata lain, variabel pemahaman mengenai pluralisme agama berpengaruh sebesar 24 persen terhadap sikap toleransi agama yang dimiliki wartawan parlemen.

\section{Kesimpulan}

Ada beberapa poin penting terkait temuan peneliti mengenai pemahaman pluralisme agama di kalangan wartawan parlemen. Pertama, pluralisme agama tampaknya disambut baik di kalangan wartawan parlemen, meskipun mereka berbeda-beda latar belakang pendidikan dan pekerjaan.

Kedua, walau secara keseluruhan mereka menerima pluralisme agama, namun ada sebagian kecil dari wartawan parlemen yang masih menganggap bahwa pluralisme agama bertentangan dengan Islam. Ini harus menjadi perhatian khusus di kalangan wartawan bahwa semangat pluralisme yang selama ini didengungkan dan disosialisasikan oleh pemerintah, ternyata tidak diterima dengan positif. Khususnya di kalangan wartawan di parlemen.

Diterimanya hipotesa alternatif dalam penelitian ini, menjadi bukti bahwa pemahaman untuk dapat menghargai dan menerima kenyataan pluralisme agama yang dimiliki bangsa Indonesia merupakan variabel penting untuk meningkatkan rasa toleransi dalam beragama. Apalagi bagi wartawan yang bertugas menyampaikan informasi-informasi penting dan mendidik kepada publik (masyarakat).

Tentunya hal yang memprihatinkan bila wartawan yang bertugas menyebarluaskan informasi dan pengetahuan yang penting bagi masyarakat tidak mampu dan mau menjaga keharmonisan antar-pemeluk agama. Karena bagaimana pun, semua warga negara Indonesia harus mau menghargai perbedaan dan menerima kenyataan pluralisme agama yang menjadi kekayaan bangsa Indonesia.

\section{Referensi}

Alwi Shihab, Islam Inklusif Menuju Sikap Terbuka, 2005

Birowo, ed., Metode Penelitian Komunikasi Teori dan Aplikasi (Yogyakarta) Gitanyali, 2004

Elvinaro Ardianto, dkk., Komunikasi Massa Suatu Pengantar (Bandung : Simbiosa Rekatama Media, 2005,

Eriyanto, Analisis Framing, Konstruksi, Ideologi dan Politik Media,

Soekanto, Soerjono .1982. "Sosiologi Suatu Pengantar", (Jakarta : CV Rajawali)

Umar Hasyim, "Toleransi dan Kemerdekaan Beragama Dalam Islam Sebagai Dasar Menuju Dialog dan Kerukunan Antar Agama”(Surabaya:PT BINA ILMU, 1979)

Lucia Ratih Kusumadewi. Sikap dan Toleransi Beragama di Kalangan Mahasiswa:Studi 
di Tiga Perguruan Tinggi di Jakarta. (.1999).

Zenuddin HM, The Journalist Buku Basic Wartawan, Bacaan Wajib Para Wartawan, Editor dan Mahasiswa Jurnalistik (Jakarta : Prestasi Pustakarya, 2007

Sudirman Tebba, Jurnalistik Baru (Ciputat : Kalam Indonesia, 2005M. Antonius Marsen, Martin H, Oxford Leaner's Pokcet Dictionary, (Oxford University, 1999), Third Edition, 3 Pius A. Partanto dan M. Dahlan Al Barry, Kamus Ilmiah Populer,

Ngainun Naim dan Achmad Sauqi, Pendidikan Multikultural mKonsep dan Aplikasi, Jogjakarta: Ar-Ruzz Media, 2008,

Syamsul Ma'arif, Pendidikan Pluralisme di Indonesia, (Jogjakarta: Logung Pustaka, 2005 